This is an electronic reprint of the original article. This reprint may differ from the original in pagination and typographic detail.

Author(s): Lämsä, Anna-Maija; Pučètaitè, Raminta; Kujala, Johanna; Heikkinen, Anna; Riivari, Elina; Medeišienè, Raimonda Agnè

Title: $\quad$ Teaching and learning business ethics in a multicultural group

Year: $\quad 2017$

Version:

Please cite the original version:

Lämsä, A.-M., Pučètaitè, R., Kujala, J., Heikkinen, A., Riivari, E., \& Medeišienè, R. A. (2017). Teaching and learning business ethics in a multicultural group. International Journal of Knowledge Management Studies, 8(1/2), 83-98.

https://doi.org/10.1504/ijkms.2017.084403

All material supplied via JYX is protected by copyright and other intellectual property rights, and duplication or sale of all or part of any of the repository collections is not permitted, except that material may be duplicated by you for your research use or educational purposes in electronic or print form. You must obtain permission for any other use. Electronic or print copies may not be offered, whether for sale or otherwise to anyone who is not an authorised user. 
Teaching and learning business ethics in a multicultural group

\author{
Anna-Maija Lämsä \\ School of Business and Economics, University of Jyväskylä \\ Jyväskylä, Finland \\ Email: anna-maija.lamsa@jyu.fi
}

\title{
Raminta Pučètaitė*
}

Kaunas Faculty Vilnius University

Kaunas, Lithuania

Email: raminta.pucetaite@knf.vu.lt

*Corresponding author

\section{Johanna Kujala}

School of Management, University of Tampere

Tampere, Finland

Email: johanna.kujala@uta.fi

\section{Anna Heikkinen}

School of Management, University of Tampere

Tampere, Finland

Email: anna.1.heikkinen@uta.fi

\section{Elina Riivari}

School of Business and Economics, University of Jyväskylä

Jyväskylä, Finland

Email: elina.riivari@jyu.fi

\section{Raimonda Agnė Medeišienė}

Faculty of Arts and Creative Technologies

Vilnius University of Applied Sciences 
Vilnius, Lithuania

Email: a.medeisiene@mtf.viko.lt

\begin{abstract}
Building on a constructivist learning theory and a case teaching method, this article suggests a mixed learning approach for teaching business ethics in a multicultural group. The purpose is to present the objectives and implementation of the mixed learning approach in a case course with a multicultural group. Based on the students' feedback, we also analyse and discuss the effects of the mixed learning approach on students' learning experiences. The article contributes to the growing stream of literature on business ethics teaching in higher education by presenting an approach that allows teachers and students to join in constructive knowledge creation in a multicultural group. In so doing, the article increases our knowledge and understanding of the effectiveness of business ethics teaching and learning, while fostering the role of diversity in business management.
\end{abstract}

Keywords: Business ethics, case teaching, constructivist learning, mixed learning, higher education, management education, multicultural group

Note: This article is a revised and expanded version of the paper entitled 'Mixed learning approach to teaching ethics in leadership and management: A case course in a multicultural group'. In Managing Complex Organization Change: Action-Oriented Approaches for Sustaining Positive Interventions. Bloomsbury Publishing India Pvt. Ltd., pp. 352-364.

Biographical notes: Anna-Maija Lämsä is a Professor of Human Resource Management at Jyväskylä University School of Business and Economics, Finland. Her main research interests are ethical approaches to management, leadership and organizations, corporate social responsibility, equality and diversity, gender and managerial careers, and women's leadership and management development. She researches these topics in different socio-cultural contexts. Her work has appeared in journals such as Journal of Business Ethics, International Journal of Human Resource Management, Scandinavian Journal of Management, Business Ethics: A European Review, Baltic Journal of Management, Gender in Management: An International Journal, Journal of Workplace Learning and Leadership \& Organization Development Journal. She is currently co-director and principal investigator in the programme Equality in Society (Weall No. 292 883) by strategic research funding of the Academy of Finland.

Raminta Pučètaitè is an Associate Professor of Business Ethics and Corporate Social Responsibility at Kaunas Faculty, Vilnius University in Lithuania and an Adjunct Professor of Management, Organizational Ethics and Human Resource Management at Jyväskylä University School of Business and Economics, Finland. Her research focuses on ethical issues in human resource management, research and academic ethics, values management and organisational 
innovativeness in a post-soviet context. She has published in national and international volumes, including Journal of Business Ethics, Business Ethics: a European Review, Baltic Journal of Management and two monographs Organisational Ethics, Innovativeness and Sustainable Innovations (Vilnius: Academic Publishing, 2015) and Ethics of Scientific Research Ethics in Lithuania (Vilnius: Lietuvos socialinių tyrimų centras, 2015).

Johanna Kujala is an Associate Professor of Business Management at the University of Tampere School of Management, Finland. She is a Docent of Business Administration (Stakeholder Management and Business Ethics) and a director of the RESPMAN (Responsible Management) Research Group at the University of Tampere. Dr. Kujala graduated as a Doctor of Science (Corporate Strategy) from University of Jyväskylä, Finland in 2001. She has a wide experience in teaching management and marketing, business ethics, stakeholder thinking and research methodology. She has acted as a visiting lecturer in several universities in Finland and as a visiting scholar at the University of Virginia and University of Chieti e Pescara. She has published almost 30 scholarly articles in journals such as Journal of Business Ethics, Business \& Society, Business Ethics: A European Review, European Journal of Innovation Management. Dr. Kujala is a member of European Business Ethics Network's (EBEN) Executive Committee as well as a member of the review boards of Journal of Business Ethics and Business Ethics: A European Review.

Anna Heikkinen (Ph.D.) is a post-doctoral researcher at the University of Tampere School of Management, Finland. She holds a Ph.D. in management and organisations. Her research areas cover corporate sustainability and climate change engagement, stakeholder theory and discourse analysis. She has published in journals such as Journal of Business Ethics, Business Communication Quarterly and South Asian Journal of Business and Management Cases.

Elina Riivari (Ph.D.) is a researcher in Jyväskylä School of Business and Economics, Finland. Her research interests include business ethics, organisational culture and innovativeness, leadership, and human resource management. She has published internationally in Journal of Business Ethics and European Journal of Innovation Management.

Raimonda Agnè Medeišienè is an expert of applied drama methods, a lecturer at Vilnius University of Applied Sciences (Lithuania), a doctoral student at Vilnius University, and president of the association "Forms of Arts". The fields of her interest are interactive drama methods, organisational ethics and interdisciplinarity. She runs workshops and gives lectures in Lithuania and abroad.

\section{Introduction}

Business management education has recently faced increased criticism for failing to develop and nurture students' ethical behaviour (e.g. Doh, 2003; Ghoshal, 2005; Kashyap et al., 2006; Lämsä et al., 2008; Mintzberg and Gosling, 2002; Moosmayer, 2012; Pfeffer and Fong, 2002). Typically, such criticism is directed at the lack of effectiveness of education in improving 
students' business performance (Ghoshal, 2005). Ghoshal (2005) argues that in fact, business management education can have a negative effect on management practice. Since teaching is often inspired by ideologically amoral theories, it leaves students lacking a sense of moral responsibility (Ghoshal, 2005). Based on their empirical study of business students' attitudinal changes during business education, Lämsä and colleagues (2008) reported that business education might contribute to a narrow view of corporate responsibility in society and a devaluation of equal-opportunity employment. Furthermore, many scholars have argued that business management education prioritises "hard" competences and instrumentalism over more feminine "soft" competences, such as interpersonal skills and personal development (Kelan and Jones, 2010; Lämsä and Savela, 2014; Lämsä et al., 2000; Simpson, 2006).

While business ethics professors have strived to advance an appreciation for and the position of ethics in business education, business manager misbehaviours imply that these efforts have not been very effective. A number of ethical scandals have been caused, at least in part, by managers' behaviours (Moosmayer, 2012). This article suggests that this situation is due to the emphasis on normative theories of ethics in education and teaching, which creates abstract ideas instead of practical viewpoints in students' thinking. Consequently, ethics teaching may not have any significant effect on students' performance. When learning the principles of right and wrong, students do not learn what moral conduct requires from them in practice (Weaver, 2006). As put by McDonald (2015, p. 511), “the dominant approach [...] constitutes an education about responsibility. Unfortunately, it cannot be deemed to be an education for responsibility."

Another challenge faced by business ethics educators and contemporary workplaces is an increasing number of issues related to diversity and multiculturalism. The growing numbers of diverse and multicultural work groups mean that people from various cultural, social and institutional backgrounds need to be able to work together productively (Chao and Moon, 2005; Laukkala, 2015). Intercultural conflicts typically result from stereotypes, miscommunications 
and misunderstandings of values, orientations, customs and knowledge (Laukkala, 2015). Though a diversity of group members can be a source of innovation and creativity (BassettJones, 2005), various values and habits can also cause interpersonal conflicts and problems (Soderberg and Holden, 2002). If not solved constructively, these conflicts may harm workplaces and decrease people's wellbeing (Hiekkataipale and Lämsä, 2015).

Many business and management classes are characterised by a unidirectional and paternalistic way of teaching, rather than by engagement with students through interaction and dialogue (McDonald, 2015). This poses a challenge for business schools to search for new ways to teach business ethics and educate their students to understand their future professions as both ethically and economically relevant (Minzberg and Gosling, 2005; Moosmayer, 2012; Nelson, Poms and Wolf, 2012). Moreover, it seems vital for business schools to develop their students' intercultural competencies so that the students are competent to solve conflicts, cooperate constructively and produce innovative ideas in multicultural and diverse groups. Developing these competencies requires empathy, attentiveness and experiences of trust to engage in productive cooperation (Freeman et al., 2015)—which, in turn, call for innovative, experiential and participative teaching methods in the classroom.

Fortunately, business ethics teaching has recently received considerable attention from scholars in the field (cf. Brinkmann et al., 2015; Freeman et al., 2015; Jonson et al., 2015; Perri et al., 2009). The literature includes insightful descriptions and reflections of innovative approaches used in business ethics teaching. For example, Shepard, Goldsby and Gerde (1997) suggested an approach for teaching business ethics based on business-related classic literature and moral philosophy. Likewise, Brinkmann (2008) advocated the use of drama literature and scenes in triggering moral reflection and imagination. Van Es (2003) proposed that the film The Insider involves moral considerations on personal, professional, organisational and public levels and could be used as an inviting cinematic introduction to applied or practical ethics. More recently, Freeman and colleagues (2015) outlined the use of creative arts, especially 
literature and theatre, in teaching business ethics. They argued that, by drawing on creative arts for both method and text, business can be more easily appreciated as a fully human activity. In addition to teaching approaches, the growing body of literature has explored criticisms of business ethics education as a short-term activity that affects students' awareness and develops their ability to recognise ethical issues, but fails to teach them how to react to or address such situations in real life (McDonald, 2015; Perri et al., 2009). Though it provides concrete examples of specific approaches, the current literature on business ethics teaching lacks a discussion of the use of various methods within a single course. We argue that, by promoting constructive and joint knowledge creation, such an approach can increase the effectiveness of business ethics teaching and learning.

Building on a constructivist learning theory (Bruner, 1973) and a case teaching method (Golich et al., 2000), we suggest a mixed learning approach for teaching business ethics in a multicultural group. The purpose of this article is to present the principles, objectives and implementation of the mixed learning approach. Based on student feedback, we also analyse and discuss the effects of mixed learning approach teaching on students' learning experiences. By describing and analysing this specific pedagogical approach, we contribute to increasing the knowledge and understanding of the effectiveness of business ethics teaching in higher business management education.

We argue that the mixed learning approach can offer a solution to the challenge of instilling ethics in the competences of business management students - the future decisionmakers. Moreover, when used to teach ethics in a multicultural group, the mixed learning approach provides opportunities to develop students' capabilities to act in a multicultural context. In the mixed learning approach, students are understood as actors who construct knowledge and meaning by themselves through various individual and social learning activities, rather than as objects of teaching, which is the typical view in the traditional teachercentred approach to teaching (Freeman et al., 2015). The mixed learning approach pays 
attention to the interaction between theoretical knowledge and practical experience; facilitates critical thinking and empathy; emphasises students' reflection, perspective-taking and participation; strives for discussion and dialogue; and increases ethical awareness and decisionmaking skills.

The article is structured as follows. Section 2 presents some central notions about the constructivist learning theory and the case teaching method and introduces the mixed learning approach. Section 3 describes the use of the mixed learning approach in teaching and learning business ethics in a course with a multicultural group of students. Next, Section 4 presents an evaluation of the course and the mixed learning approach. The article ends with a discussion and some concluding remarks.

\section{Bases of mixed learning approach: Constructivist learning and case teaching}

According to the constructivist learning theory, learners (i.e. students) are regarded as active participants instead of passive receivers of knowledge in learning situations (Atherton, 2013). While making meaning in relation to a topic that is taught and learnt, students actively construct new concepts, ideas and meanings by drawing on their past and current knowledge (Bruner, 1973). Consequently, the use of cultural, social and situational knowledge, practical experiences, theoretical concepts and frameworks is important. According to Piaget (1955), the process of assimilation helps learners position new ideas and experiences within the context of old ones, stimulating them to rethink and reframe their former knowledge and to integrate new experiences and/or ideas into their existing mental structures and schemas. Accommodation, another important idea proposed by Piaget (1955), refers to the process by which experiences and perceptions transform learners' knowledge bases and capacities as the learners create new patterns of a topic. 
According to constructivism, learners can reach a "zone of proximal development" in their learning processes (Vygostky, 1978). Students can, for instance, learn business ethics from their experiences in practice. However, there is a difference between what a student can learn without help and what she/he is able to accomplish if she/he receives support in the process of learning and development (Atherton, 2013). Some students may have very limited experience of ethical dilemmas because of their considerably short working lives or lack of ethical reflection due to socialisation in predominantly profit-oriented business contexts. While spontaneous learning is important, students may not be able to make significant advancement without proper assistance, facilitation and support (Atherton, 2013). Therefore, learners need support from instructors.

The case teaching method combines practical and theoretical knowledge in business ethics education (Golich et al., 2000). In general, the case teaching method puts learners in the roles of people who need to make decisions or act appropriately in specific events or situations. This increases students' opportunities to position themselves in the situation of a decisionmaker and can foster students' understanding of what it means to be a responsible moral agent (Weaver, 2006).

Cases often relate to real-life events (e.g. a company and its operations), but they can also be fictional or imaginary (e.g. a film or a novel). In general, a case can be described as a story that highlights events, dilemmas and problems in such a way as to allow learners to experience the ambiguities, complexities and uncertainties of the ethical issues confronted by the story participants (Golich et al., 2000). Teaching with cases allows students to actively seek new information and to construct alternative solutions, rather than passively accepting a teacher's views about the decision in question.

Previous studies have shown that group diversity increases solution quality in brainstorming (Cox et al., 1991) and improves innovativeness (Miller and del Carmen Triana, 2009). Thus, a multicultural learning environment with students from diverse backgrounds 
presents broader and more diverse views on a topic than a homogeneous group (Vygostky, 1978). Yet, the relationship between diversity and performance can be curvilinear, such that too little or too much diversity may be detrimental to performance (Webber and Donahue, 2001). Building on the constructivist learning theory and the case teaching method, we suggest using the mixed learning approach to enhance the teaching and learning of business ethics in a multicultural group. This mixed learning approach stresses the social form of constructivism, which presumes that learners are constructing new ideas and meanings through common learning together and with the teacher. Therefore, social interaction has a pivotal role in learning (Vygostky, 1978). Additionally, the mixed learning approach adopts Piaget's (1955) idea that learners construct their understandings through various methods and channels, such as reading, discussing, listening, telecommunication tools, software education tools, videos, elearning etc. Therefore, teaching based on constructivism needs to provide and use several methods and activities to be able to challenge diverse learners' existing knowledge.

Using the mixed learning approach in teaching and learning business ethics involves several methods and activities (e.g. cases, applied drama, e-learning), which are used to provide numerous and varying platforms and chances for learners to practice social interaction in various ways. If one activity does not suit some of the learners, another activity may be appropriate. This is particularly fruitful in multicultural student groups, in which students' learning styles and backgrounds vary. In the next section, we will describe using the mixed learning approach to develop and teach a business ethics course with a multicultural group of students.

\section{Using the mixed learning approach in teaching and learning business ethics}

\subsection{Planning the course}


With the goal of creating a business ethics course for future business decision makers based on the mixed learning approach, university teachers and professors from five countries-namely, Estonia, Finland, Latvia, Lithuania and Norway—developed a Baltic-Nordic context-sensitive higher education course at the master's level called "Cases in Organizational Ethics."

Following the idea of the mixed learning approach, the course was designed to constructively align attention to both teaching and learning outcomes and the assessment of these outcomes. In constructive alignment, each outcome statement contains a learning activity, which incorporates a verb that students need to perform to best achieve the outcome: for example, "analyse ethical problems" or "create proposals". This verb articulates important learning activities that students need to undertake in order to achieve the intended learning outcome. Learning is constructed by the activities that students carry out; thus, learning is about what the students do, not about what the teachers do (Biggs, 1996). The role of the teacher is to support and encourage the students' learning processes and to provide them with appropriate conditions and tools (Atherton, 2013).

The learning targets for the course were set to meet the relational and extended abstract levels of the Structure of the Observed Learning Outcome (SOLO) taxonomy (Biggs, 1995), as well as the master's level course in the Bologna process (Sweeney, 2011). The SOLO taxonomy allows the teacher to assess students' work in terms of its quality, rather than what the students do or do not know. The idea is that, first, students pick up only one or a few aspects and relate them through the learning process (i.e. moving from uni-structural to multistructural). Next, the students are able to reach the relational level, at which an adequate understanding of the topic is reached. Finally, at the extended abstract level, the students are able to conceptualise the new whole at a higher level of abstraction and generalise it to a new topic or area. The last two levels require qualitative assessment (Biggs, 1995). 
As learning progresses, it becomes more complex. At the master's level, learning outcomes need to be expressed at the relational and extended abstract levels. Following this idea, the learning objectives for the course were planned as follows.

By the end of the course, the student will be able to:

1 recognise and critically reflect on the ethical dimensions of organisational life;

2 analyse, evaluate and solve ethical problems through theoretical frameworks;

3 act as a moral decision-maker in ethically challenging situations and participate constructively in a moral dialogue in a multicultural group; and

4 create proposals and argue for how ethics can be promoted by management and leadership activities in different organisational and socio-cultural contexts.

\subsection{The course content}

The course content was planned to address the most prevalent and current topics in the field of business and organisational ethics. The course topics addressed the following issues:

1 ethical leadership, ethics management and an ethical workplace;

2 stakeholder theory and management; 
The first topic on ethical leadership, ethics management and an ethical workplace focused on defining and distinguishing ethical and unethical leadership and how leaders can motivate others to act ethically in uncertain situations. The second topic, stakeholder theory and management, addressed questions concerning business' role in society, how stakeholder management affects corporate reputation, and stakeholder dialogue. Third, the topic of gendered organisations and diversity management considered how gendered organisations are created and explored business benefits and risks related to diversity programmes. The fourth topic of corporate psychopathy and decision-making discussed the characteristics of corporate psychopaths and the relations among leadership practices, follower behaviours and organisational culture. The topic of risk and responsibility focused on the constitutions of risk and responsibility at individual and organisational levels, as well as on distinguishing and managing ethical risks.

Four teaching cases were written for the course purposes. Most of these cases were published in the textbook Cases in Organizational Ethics (Pučètaitè, 2012), and they were available to the students through an online platform. In addition to the cases, the course material included relevant readings introducing theoretical approaches to the studied topics. The following chapters describe the cases and their use in the classroom, as well as other forms of the mixed learning approach used in the course.

The Nokia Case and A Clothing Company Case focused on the ethical challenges and problems of a Western company operating in a developing country. The classroom activities 
were based on the documentary film A Decent Factory, directed by Thomas Balmes (2004), and the BBC report Dying for a Bargain (2013). The aim was to reflect the reality and challenges of embedding organisational ethics, in particular, in human resource management practices in a globalising world. Additional aims were to discuss ethical problems from conceptual and practical viewpoints and to learn some of the frameworks of ethical organisations. Before watching the film, the students organised themselves into pairs within small groups of four people. As each group watched the film, one pair paid attention to problems arising for the subcontractor, the employees and the company as a result of actions portrayed in the film. The other pair paid attention to advantages received by the subcontractor, the employees, and the company. After the film, small groups discussed their views and prepared to defend them. This helped the students gain a broader perspective of the topic and avoid moralising. Finally, a discussion of the whole group of students followed. Theoretical frameworks and concepts were presented during the final discussion, which was moderated by two instructors applying team teaching.

The Botnia Case focused on the use of stakeholder dialogue in a conflict situation. The case described a situation in which a multinational company's foreign investment raised both opposing and supporting views among local stakeholders (Heikkinen et al., 2012). The aim in the classroom was to deepen the students' understanding of the multitude of stakeholder interests and to advance their skills in facilitating a dialogue in order to find solutions and avoid a conflict. The students were instructed to act in different stakeholder roles and, thus, empathise with the different stakeholder views in order to understand the complexity of the situation. Team teaching of two instructors was also applied in this case.

The Nina Case focus on gendered practices in organisations and, specifically, on the barriers to women's careers. A fictive case developed based on 38 women managers' stories of their experiences in real working life (Lämsä et al., 2012) presented challenges in the career advancement of a person called Nina. The aim in the classroom was to facilitate students' 
understanding that managerial careers in organisational life are not gender-neutral; rather, career development tends to be gender-sensitive. Another aim was to describe and analyse different gendered practices from the viewpoint of managerial careers and to reflect their advantages and disadvantages. The students discussed the case in small groups, and each group prepared a presentation of the discussion outcomes for the other groups. Analysing the Global Gender Gap Report of the World Economic Forum, which students were asked to read before the course, complemented the case discussion and added a socio-cultural aspect to the reflection of a woman's professional career. Again, two instructors presented theoretical frameworks and concepts during the final discussion.

The corporate psychopathy session consisted of a theoretical explanation of the phenomenon and its relation to the concepts of unethical, destructive and toxic leadership. In addition, statistical data and mini cases were addressed, and the students completed exercises using psychological techniques to raise self-awareness and reflect unconscious desires for power. The aim of these exercises was to develop students' skills in recognising situations in which power starts to take control over a personality, superseding human remorse. The ability to empathise was reflected as a measure to prevent the devastating consequences of destructive leadership and toxic organisational environments at individual, organisational and societal levels. The group discussion was complemented by a drama exercise aimed at deepening students' understanding of sometimes subtle forms of destructive leadership and the effects it may produce.

Applied drama methods were used to support case teaching as relatively brief interventions leading to reflection and common discussions of ethical issues. The main responsibility of the applied drama methods practitioner was to build a safe and trusting environment for learning, communication and teamwork, taking into account the differences in the course participants' ages, professional experiences, nationalities, cultures and social skills. The students' level of English, knowledge of business ethics and motivation to take part in the 
programme also varied. The use of applied drama methods varied from relatively simple techniques (e.g. team building) to the more complex ones. The applied drama methods were explained to the students shortly before they were used, and their application created room for the students' spontaneous reactions, behaviours, cooperation and learning.

A company visit was organised as part of the course to assist in classroom learning. The companies in the visit were selected based on their ethical and/or environmental awareness and the respective principles that they applied in practice.

\subsection{Carrying out the course}

The course was carried out in the following three phases, which the students needed to complete in order to pass:

1 preparing for the intensive course through e-learning;

2 participating in a six-day intensive course; and

3 completing an independent study journal.

In the first phase, the students independently familiarised themselves with the course topics and the course materials available in an online learning environment. All course materials, including a detailed course description, cases, articles and student and teacher introductions were made available through the online platform. To ensure proper preparation for the face-toface classes, the students were instructed to read the pre-selected articles addressing the course topics and to write a short essay summarising each of the articles. 
The intensive courses took place in Tallinn, Estonia, in 2013; in Oslo, Norway, in 2014; and in Riga, Latvia, in 2015. The courses had 12, 22 and 19 students, respectively. Each year, the student composition was diverse in terms of nationality and socio-cultural background. Additionally, the composition varied to some extent by age (ranging from early twenties to fifties), working experience (some students had extensive professional experience in managing positions), and gender (female students were the majority).

After the intensive course, the students were instructed to write a study journal based on the course literature and the class experience. The study journal had to be a reflective text that covered the central theories, concepts and research in the area, as well as their personal processes of becoming familiar with the studied topic. The study journal consisted of two parts: a concept map and a critical essay. In the first part, the students were expected to examine the course topics as a comprehensive and coherent whole. A concept map had to disclose the students' understanding of the key concepts, including their relationships, hierarchies, similarities, contradictions etc. In the second part, the students could focus more on a specific topic/problem/phenomenon of their own interest. For example, in the field of ethical leadership and human resource management, the students could choose to look more closely at how ethical leadership relates to other leadership theories. The students had to examine their chosen topics critically from various perspectives and theoretical viewpoints based on the course literature. Students were encouraged to ask questions and express their own thoughts on the readings.

Detailed instructions how to write a study journal and the evaluation criteria for the assignment were provided to the students through the online learning environment. Examples of concept maps and programs for devising them were also provided.

\section{$4 \quad$ Evaluating the course and the mixed learning approach}




\section{$4.1 \quad$ Collecting feedback}

Student feedback was collected after each course round. After the first and third rounds, an internet survey was used. The first-round survey consisted of 22 statements in four thematic blocks related to the quality of the online course management (e.g. The structure of the course in the Moodle environment was clear), gained knowledge (e.g. The course provided an opportunity for self-reflection), overall satisfaction with the course (e.g. The course met my expectations) and evaluation of the cases (e.g. Please evaluate the course topics by their potential to spark your interest).

The statements were evaluated on a 7-point Likert scale, ranging from 1 (totally disagree) to 7 (totally agree). Open-ended questions for students'suggestions for course improvements and comments on their highest/lowest evaluations were included. In the third round, twelve new statements were added to the survey to cover new content and teaching methods (e.g. applied drama methods), and the scale was changed to a 5-point Likert scale, ranging from 1 (totally disagree) to 5 (totally agree). The students completed the survey after submitting their study journals for grading. The survey response rate was $67 \%$ after the first round and $84 \%$ after the third one.

In the second round of the course, feedback was collected after the last class. The students were asked to write down their views on the course's advantages and their suggestions for improvements. After that, they were asked to give a short oral evaluation of the course, which was followed by a group discussion on what could be improved and how. This type of feedback was aimed at eliciting both rational and constructive comments and emotional reactions to the course.

\subsection{Students' evaluations and experiences}


Overall, the students' feedback indicated that they perceived the importance of "soft issues" in their education and that they believed that the multicultural interaction during the intensive course added value to their future careers and work. Students appreciated the opportunity to relate to others with similar values and to be "not the only ones who believe that ethics is important'. Moreover, they acknowledged that cultural backgrounds cannot be taken for granted when speaking about ethics and following values in practice: "I do not take itfor granted any more that ethical and environmental points of view are familiar to all business students".

From the perspective of gained knowledge, most students were positive about their progress and evaluated it well above average. From the content perspective, leadership topics (i.e. ethical and psychopathic leadership) were evaluated as among the most interesting topics in the first and third rounds, followed by the topics of gendered organisations and ethical workplaces. In particular, the third-round class on ethical workplaces in developing countries was reported as eye-opening. Eventually, the introduction of the applied drama methods was reported as improving cognitive abilities by offering moments of relaxation and fun. In addition, the applied drama methods exercises articulated a particular theme studied through a particular case, giving a twist to the already gained knowledge.

Although the organisers made efforts to facilitate group dynamics and networking by organising a get-together dinner on the day of arrival and encouraging the students to have more intensive social lives after the classes, there were remarks in all rounds that an organised course excursion or other social program would be beneficial. This was least problematic during the first round, in which the group of students was the smallest and the hosting institution recruited a representative number of students who took care of the group's social life. This first-round aspect contributed to the group dynamics and enhanced the focus of the discussions. 
The most important challenge was to ensure that students with diverse backgrounds experience similar learning progress. In this course, there were students who had already been studying related topics for at least one year and others for whom this was their first course in the field of business and organisational ethics. As a result, some students were learning much more than others; this was reflected in the feedback. To address this challenge, before the course, the instructors explained to the more advanced students that they should consider the whole course as a learning experience and that, if they already knew some of the course content, they could take on the role of experts and share their knowledge with the other students. Moreover, the students were encouraged to reflect on particular topics more deeply in their study journals.

\section{$5 \quad$ Discussion and conclusions}

The article contributes to the growing stream of literature on business ethics teaching and learning in higher education and presents the mixed learning methods approach that allows both teachers and students to join in constructive and aligned courses and classroom meetings with multicultural groups addressing the problems and challenges of business and organisational ethics. In so doing, the mixed learning approach increases our knowledge and understanding of the effectiveness of business ethics teaching and learning, while fostering the role of diversity in managerial decision-making.

Team teaching, several instructors and a multiplicity of methods proved advantageous for the effective learning and teaching of business and organisational ethics. A combination of experience-based exercises and theoretical learning had a significantly higher effect on learners' understanding of the studied cases and related problems and phenomena than the sole application of either approach. Discussion and dialogue between instructors and learners are 
useful in case teaching, but they require both parties to develop their communication competence, interaction and social skills. This is particularly important in cases of multicultural groups. All of these aspects should be considered when recruiting students and teachers for a course.

A diverse group in terms of ethnicity, age, gender, knowledge level and work experience, is useful in a case course; however, students need to be trained to face and address diversity before participating. Otherwise, there is a risk of people passing the course with disdainful attitudes toward people of different nationalities or backgrounds, resulting from different understandings of ethics and morality or distinctive experiences of responsible and sustainable business practices. In addition, it is important that the group not be too big. In our experience, the group size should not exceed 20 persons, since any larger size undermines opportunities to analytically discuss the group work, sufficiently examine the cases or critically prepare the presentations. Too large of a group can also create an impression of haste and cause a superficiality of discussion.

The course also revealed that, though experiential learning through applied drama methods can create several positive emotions, it is an intervention activity that can also arouse painful experiences. An instructor must be prepared to confront and consider such experiences in learning situations. It is important for participants to be able to leave the session with positive attitudes and emotions.

Our experiment proved that a company visit is considered a useful component in teaching and learning business ethics. However, it is important to prepare such a visit carefully. Students should familiarise themselves with the company and the aim of the visit beforehand and the teachers should agree on the purpose of the visit with the company representatives in advance. Moreover, the company representatives should have information on the course, its purpose and its participants in order to plan the visit successfully to meet students' and teachers' expectations. It is also useful for the students to prepare questions to which they can seek 
answers during the visit. Requiring a company analysis from the students after the visit could further increase their chances of achieving the desired learning outcomes.

Drawing on the ideas of constructive learning and case teaching, the mixed learning approach presented in this article stresses the importance of using several teaching methods, activities and tools in the effective learning and teaching of business and organisational ethics. We suggest that the mixed learning approach considers differences in learners' learning styles, giving it an advantage over the single-method approach when teaching business ethics. This is important because, though students tend to process and construct knowledge in various ways, many teachers tend to prefer a specific teaching style or a mixture of styles, such as lecturing, conversation, drama, role playing, etc. This creates a challenging situation, in which it can be difficult to match students' learning styles with teachers' teaching styles. Therefore, we conclude that the mixed learning approach can enhance the effectiveness of students' learning, especially in a multicultural group when a course is organised by several instructors using team teaching.

The results of the case course analysis indicate that, in general, student diversity can be an advantage when teaching and learning business ethics. Diversity in work experience, gender, age and nationality proved fruitful for this course. However, too much diversity in students' prior knowledge bases can create challenges related to co-operation and social cohesion, especially if the students are not trained before the course to address these kinds of differences. It was observed that some of the students in the course who had clearly greater knowledge of the topic valued themselves above others and complained about their restricted ability to learn new things. When these differences in competence occur between specific participant nationalities, as they did in this case, there is a risk of nationality becoming understood as a source of incompetence, resulting in negative stereotyping of nationalities. This challenge was successfully addressed by explaining to the students that differences in basic knowledge level 
existed in the course and that more advanced students should take responsibility for helping others and facilitating learning.

The course proved that applied drama methods are helpful in teaching and learning business ethics because they can contribute to building a constructive and open team atmosphere among students. This is particularly important in multicultural and diverse groups, in which misunderstandings and their resulting challenges can be greater than in a homogeneous group. For this reason, instructor competence in organising motivating drama exercises, addressing group dynamics and handling various emotional reactions is crucial. In general, we suggest that group learning, which is an important aspect of the mixed learning approach, can be more effective in diverse groups than in homogenous groups.

Finally, we argue that the success of teaching and learning business ethics depends on the extent to which the situations addressed relate to practice and on the students' ability to use their moral imagination in addition to applying ethical theories. Positive experiences increase students' motivation to learn and create more meaningful learning outcomes; thus, they can overcome the challenges of learning business ethics and become more responsible business professionals. Teaching must be organised to create conditions that allow students to understand what is expected and required of them and to advance their own thinking, reflection and imagination of the topic. Thus, both clear instructions and spontaneous learning situations are necessary.

\section{Acknowledgements}

This research was supported by This research was supported by Nordplus Higher Education program (Project No. HE-2012_1a-29101) and the program Equality in Society (Weall No. 292 883) by strategic research funding of the Academy of Finland. We gratefully acknowledge their support. 


\section{References}

Atherton J.S. (2013) Learning and teaching; Constructivism in learning.

http://www.learningandteaching.info/learning/constructivism.htm.

Bassett-Jones, N. (2005) The Paradox of Diversity Management, Creativity and Innovation.

Creativity and Innovation Management, Vol. 14, No. 2, pp.169-175

Biggs, J. (1995) 'Assessing for learning: Some dimensions underlying new approaches to educational assessment', The Alberta Journal of Educational Research, Vol. 41, No. 1, pp.1-17.

Biggs, J. (1996) 'Enhancing teaching through constructive alignment', Higher Education, Vol. 32, pp.347-364.

Brinkmann, J. (2008) 'Using Ibsen in business ethics', Journal of Business Ethics, Vol. 84, No. $1, \mathrm{pp} .11-24$.

Brinkmann, J., Lindemann, B. and Sims, R.R. (2015) 'Voicing moral concerns: Yes, but how? The use of Socratic dialogue methodology', Journal of Business Ethics, DOI: $10.1007 / \mathrm{s} 10551-015-2655-8$.

Bruner, J. (1973) Going beyond the information given. Norton, New York.

Chao, G.T. and Moon, H. (2005) 'The cultural mosaic: A metatheory for understanding the complexity of culture', Journal of Applied Psychology, Vol. 90, No. 6, pp.1128-1140.

Cox, T., Lobel, S. and McLeod, P. (1991) 'Effects of ethnic group cultural differences on cooperative and competitive behavior on a group task', Academy of Management Journal, Vo. 34, No. 4, pp.827-847.

Doh, J.P. (2003) 'Can leadership be taught? Perspectives from management educators', Academy of Management Learning and Education, Vol. 2, No. 1, pp.54-67. 
Es, R. van (2003) 'Inside and outside The Insider: A film workshop in practical ethics', Journal of Business Ethics, Vol. 48, pp.89-97.

Freeman, R.E., Dunham, L., Fairchild, G. and Parmar, B. (2015) 'Leveraging the creative arts in business ethics teaching', Journal of Business Ethics, Vol. 131, pp.519-526.

Ghoshal, S. (2005) 'Bad management theories are destroying good management practices', Academy of Management Learning \& Education, Vol. 4, No. 1, pp. 75-91.

Golich, V.L., Boyer, M., Franko, P. and Lamy, S. (2000) The ABCs of case teaching. Pew Case Studies in International Affairs. Institute for the Study of Diplomacy, Edmund A. Walsh School of Foreign Service, Georgetown University.

Heikkinen, A., Kujala, J. and Lehtimäki, H. (2012) 'Stakeholder dialogue: MNE green field investment in Uruguay' in Sardana, G.D. and Thatchenkery, T. (Eds.): Capability Building for Organizational Transformation. Management Cases from Multiple Disciplines, pp. 50 - 65, Bloomsbury, New Delhi.

Hiekkataipale, M. and Lämsä, A-M. (2015) 'What should a manager like me do in a situation like this? Strategies for handling ethical problems from the viewpoint of the logic of appropriateness', Journal of Business Ethics, (DOI) 10.1007/s10551-015-2911-y.

Jonson, E.P., McGuire, L.M. and O’Neill, D. (2015) 'Teaching ethics to undergraduate business students in Australia: Comparison of integrated and stand-alone approaches', Journal of Business Ethics, Vol. 132, pp. 477-491.

Kashyap, R., Mir, R. and Iyer, E. (2006) 'Toward responsive pedagogy: Linking social responsibility to firm performance issues in the classroom', Academy of Management Learning \& Education, Vol. 5, No. 3, pp. 366-376.

Kelan, E.K. and Jones, R. D. (2010). Gender and the MBA. Academy of Management Learning \& Education, Vol. 9, No. 1, pp.26-43. 
Lämsä, A-M. and Savela, T. (2014) 'The effect of an MBA on the development of women's management competencies: a gender viewpoint', Baltic Journal of Management, Vol. 9, No. 2, pp.213-230.

Lämsä, A-M, Jyrkinen, M. and Heikkinen, S. (2012) 'Why is she getting annoyed with minor issues? Case Nina' in Pučètaitè, R. (Ed.): Cases in Organizational Ethics, pp.18-23, Vilnius University, Vilnius. http://decom.vukhf.lt/book.

Lämsä, A-M., Säkkinen, A. and Turjanmaa, P. (2000) 'Values and Their Change During Business Education - A Gender Perspective', International Journal of Value-Based Management, Vol. 13, No. 3, pp. 203-213.

Lämsä, A-M., Vehkaperä, M., Puttonen, T. and Pesonen, H-L. (2008) 'Effect of business education on women and men students' attitudes to responsible business in society', Journal of Business Ethics, Vol. 82, No. 1, pp.45-58.

Laukkala, J. (2015). Third party in workplace conflicts: the mediator's conflict management and intercultural competences, Jyväskylä Studies in Business and Economics 162, Doctoral dissertation, University of Jyväskylä, Jyväskylä.

McDonald, R. (2015) 'Leveraging change by learning to work with the wisdom in the room: educating for responsibility as a collaborative learning model', Journal of Business Ethics, Vol. 131, pp. 511-518.

Miller, T. and Del Carmen Triana, M. (2009) 'Demographic diversity in the boardroom: mediators of the board diversity-firm performance relationship', Journal of Management Studies, Vol. 46, No. 5, pp.755-786.

Mintzberg, H. and Gosling, J. (2002) 'Educating managers beyond borders', Academy of Management Learning \& Education, Vol. 1, No. 1, pp. 64-76. 
Moosmayer, D.C. (2012) ‘A Model of Management Academics’ Intentions to Influence Values', Academy of Management Learning \& Education, Vol. 11, No. 2, pp. 155-173.

Nelson, J., Poms, L.W. and Wolf, P. (2012) 'Developing efficacy beliefs for ethics and diversity management', Academy of Management Learning \& Education, Vol. 11, pp. 49-68.

Nevgi, A. and Lindblom-Ylänne S. (2009) 'Opetuksen linjakkuus - suunnittelusta arviointiin’ in Lindblom-Ylänne, S. and Nevgi A. (Eds.): Yliopisto-opettajan käsikirja, pp.138-155, WSOYpro, Helsinki.

Pfeffer, J. and Fong, C.T. (2002) 'The end of business schools? Less success than meets the eye', Academy of Management Learning \& Education, Vol. 1, No. 1, pp.78-95.

Perri, D.F., Callanan, G.A., Rotenberry, P.F. and Oehlers, P.F. (2009) 'Education and training in ethical decision making: Comparing context and orientation', Education and Training, Vol. 51, No. 1, pp.70-83.

Piaget, J. (1955) Construction of Reality in the Child, Routledge \& Kegan Paul, London.

Pučètaitè, R. (Ed.) (2012) Cases in Organizational Ethics, Vilnius University, Vilnius. http://decom.vukhf.lt/book.

Sheppard, J.M., Goldsby, M.G. and Gerde, V.W. (1997) 'Teaching business ethics through literature', Teaching Business Ethics, Vol. 1, No. 1, pp.33-51.

Simpson, R. (2006) 'Masculinity and management education: Feminizing the MBA', Academy of Management Learning \& Education, Vol. 5, No. 2, pp.182-193.

Soderberg, A-M. \& Holden, N. (2002) 'Rethinking cross cultural management in a globalizing business world', International Journal of Cross Cultural Management, Vol. 2, No. 1, pp.103-121.

Sweeney, S. (2011) Writing learning outcomes in higher education, University of York, UK. Vygotsky, L.S. (1978) Mind in Society, Harvard University Press, Cambridge, MA. 
Weaver, G. (2006) 'Virtue in organizations: Moral identity as a foundation for moral agency', Organization Studies, Vol. 27, No. 3, pp.341-368.

Webber, S. and Donahue, L.M. (2001) Impact of highly and less job-related diversity on work group cohesion and performance: A meta-analysis', Journal of Management Studies, Vol. 27, pp.141-162. 